Kirgizbekova, S.S. (2021). Historical and cultural significance of the collection of Russian artists in the A. Kasteeva Museum. Klironomy, 1 (1), 110-126. Hlučín-Bobrovníky: “Anisiia Tomanek” OSVČ.

Киргизбекова, С.С. (2021). Историко-культурная значимость колмекции русских художников в музее им. А. Кастеева. Klironomy, 1 (1), 110-126. Hlučín-Bobrovníky: “Anisiia Tomanek” OSVČ.

DOI: $10.47451 /$ her2021-04-004

EOI: $10.11249 /$ her2021-04-004

The paper is published in Crossref, Internet Archive, Google Scholar, Academic Resource Index ResearchBib, JGate, ISI, CiteFactor, ICI, eLibrary databases.

Svetlana S. Kirgizbekova

Member of the Union of Designers Kazakhstan senior lecturer

Department of Creative disciplines Abai Kazakh National Pedagogical University

Almaty, Kazakhstan

E-mail: sveta010161@mail.ru

\title{
Historical and cultural significance of the collection of Russian artists in the A. Kasteeva Museum (in Russian)
}

\section{Abstract:}

The article is devoted to the collection of Russian art, presented today in the State Museum of Arts. Abylkhana Kasteeva in Almaty. Practice has shown that the main stream of artistic forces rushed to Kazakhstan from Moscow. The value of the entire Kazakh exposition of the museum is colossal not so much in material terms as in its historical and cultural significance for descendants and contemporaries. In the context of the style diversity of images, shapes and colors, one can grasp the sensations, and through them to find answers to many questions, understand the historical processes in Kazakhstan, beliefs, our attitude to nature, to life and to each other. Therefore, it is so important to identify the circle of artists who worked in Kazakhstan, in the years when Kazakhstan's fine arts were just getting on their feet, the process of consolidating a few creative forces was taking place. Anyway, these artists visited Kazakhstan, worked here, created their own works. Among them were eminent Russian painters, who entered the history of Soviet Art. The masterpieces of Kazakh and Russian art will allow the viewer to trace the history of the formation and development of the Kazakh national school of painting, over a thousand paintings, prints and drawings are the pride of the collection of the State Museum of Arts of Kazakhstan. A. Kasteev.

Keywords: art, museums, creativity, artists, history, culture, painting, collection, exhibits, exhibition.

Светлана Сейсенбаевна Киргизбекова член Союза Аизайнеров Казахстана ст. преподаватель Кафедра творческих специальностей 
Казахский национальный педагогический университет им. Абая

А^маты, Казахстан

E-mail: sveta010161@mail.ru

УАК 7.067:316.37

МРНТИ18.07.23

\section{Историко-кумьтурная значимость комлекции русских художников в музее им. А. Кастеева}

Aннотачия:

Статья посвящена коллекции русского искусства, представленная в наши Ани в Государственном музее искусств им. Абылхана Кастеева в Алматы. Практика показала, что основной поток художественных сил устремлялся в Казахстан из Москвы Ценность всей казахстанской экспозиции музея колоссальна не столько в материальном выражении, сколько в ее историко-культурной значимости Аля потомков и современников. В контексте стилевого многообразия образов, форм и цветов, можно уловить ощущения, а через них найти ответы на многие вопросы, понять исторические процессы в Казахстане, убеждения, наше отношение к природе, к жизни и Аруг к Аругу. Поэтому столь важно выявить круг художников, работавших в Казахстане, в годы, когда казахстанское изобразительное искусство только становицось «на ноги», происходиц процесс консолиАации немногочисленных творческих сил. Так или иначе, эти художники побывали в Казахстане, работали здесь, создавали свои произведения. Среди них были именитые русские живописцы, вошедшие в историю советского искусства. Шедевры казахского и русского искусства позволят зрителю проследить историю становления и развития казахской национальной школы живописи, свыше тысячи картин, гравюр, рисунков явАяются гордостью собрания Государственного музея искусств Казахстана им. А. Кастеева.

Ключевъе слова: искусство, музеи, творчество, художники, история, культура, живопись, комлекция, экспонаты.

\section{Введение}

Актуальность Аанной темы обусловлена значимостью в ценности всей казахстанской экспозиции музея и колоссацьна не столько в материацьном выражении, сколько в ее историко-культурной значимости Аля потомков и современников. В контексте стилевого многообразия образов, форм и цветов, можно уловить ощущения, а через них найти ответы на многие вопросы, понять исторические процессы в Казахстане, убеждения, наше отношение к природе, к жизни и Аруг к Аругу. 
Предметом исследования в статье является Музей искусств им. Кастеева и кол^екция русского искусства.

Цель Аанной статьи исследовать первые и последующие шаги в развитии музейного Аела страны, проследить исторический путь становления музея за Аовольно большой период.

Исходя из поставленной цели были определены следующие задачи:

- рассмотреть, как происходило становление музея в первые годы советской вАасти, приводя конкретные исторические примеры деятельности тех или иных мичностей, с ними связанных;

- исследовать развитие музейного дела в последующий период, то есть начиная с 1920-х гг. и до Великой Отечественной Войны;

- изучить цели и заАачи, поставленные переА советским музеем политической властью страны;

- исследовать Аальнейшие этапы музейного пополнения, важнейшие события в музейной истории, государственную политику в этой области, состоявшиеся проекты.

В ходе исследования применялся метод анализа, сравнение, а также изучение разАичных подходов - исторический, теоретический, музеографический, биографический.

Аля реализации исследования использовались труды ведущих специалистов в Аанной области, например, руководителя Центра классического зарубежного искусства музея имени Кастеева Г.Н. Сырлыбаевой, руководителя Государственного музея искусств Республики Казахстан имени А. Кастеева Гульмиры Шалабаевой, культурного обозревателя А. Азарова, живописца В. Бакшеева, а также М.К. Козыбаева и Р.Н. Нургалиева.

\section{Историко-кумьтурная значимость коммекции}

В силу ми своей удалённости от центральных городов России, сложившейся $\Lambda и$ культурной традиции, то Казахстан, как объект эстетического освоения, Аолгое время не бы столь популярен у московских или менинградских художников в так называемый советский период. Это, конечно, связано и с незначительным информационным потоком, освещающим и представляющим регион. Материалы научноисследовательских экспедиций в Казахстан, в состав которых, как правило, входили и художники, фиксировавшие в силу своих творческих 
возможностей увиденное, оставались Аостоянием небольшого круга ученых и заинтересованных миц. Возможные приезды каких-либо художников не освещались ни местной, ни центральной печатью, оставались незамеченными, в силу отсутствия художественной среды и общественного интереса к изобразительному искусству в республике в 1920-е гг. Среди них были именитые русские живописцы, вошедшие в историю советского искусства и малоизвестные сегодня - от академистов и передвижников Ао художников, пропагандирующих идеи «Бубнового валета», «Цеха живописцев», «Бытия» и т.А.

В 1920-е гг., а это первый этап, приезжали самые пытАивые художники по зову собственных творческих интересов, в поисках новых впечатлений, сюжетных мотивов, живописных открытий и экспериментов.

1930-е гг. - новая волна интереса к Казахстану в связи с актуализацией темы инАустриализации в советском изобразительном искусстве. Как правило, художники приезжали весной, в апреле-мае, и работали до поздней осени - сентября-октября.

И третий этап связан с периодом Великой Отечественной войны, когАа республика приняла более ста художников, организовав их быт и творческий процесс (Основатель алматинского Барбизона).

Колмекция русского искусства, преАставленная в наши Ани в Государственном музее искусств им. Абылхана Кастеева в Алматы, - самая богатая во всей республике как в художественном, так и в материальном смысле. История её появления в Казахстане началась ровно 80 мет назац.

В прошлом веке советские власти задумали приобщить все население СССР к всемирному культурному наследию. И вынудили «головные офисы» Эрмитаж и Пушкинский музей - Аелиться своими сокровищами с региональными российскими и республиканскими музеями. Так, в 1936 году музей в Алматы получил в дар первые произведения из Москвы, которые по сей Аень составляют основу колмекции живописи Западной Европы (А^маАта, 1983).

Во многих респуб์ликах стали образовываться такие очаги культуры, как музеи. У нас в Алма-Ате с 1935 г. существовала художественная галерея (будущий ГМИ РК им. Кастеева). По воспоминаниям искусствоведа Марии Копелиович «имеется приказ Алиби Ажангильдина, который обратился к тогАашнему наркому просвещения Андрею Бубнову о выделении из музейных фондов Москвы и Аенинграда мировых шедевров. Галерея получила около ста произведений из Музея изящных искусств (ныне - 
Государственный музей изобразительных искусств им. А.С. Пушкина). Из них 20 - живопись. В то время Ааже москвичи не знали, насколько будут знамениты имена художников, чьи произведения сегодня атрибутированы. Некоторые работы были удивительные, сейчас мы на них не нарадуемся» (Азаров, 2012).

Практически все работы из первого поступления экспонируются в зале. Так в 1936-39 гг. крупнейшие музеи Москвы и Аенинграда - Третьяковская галерея, Русский музей, Государственный музей искусств им. А. Пушкина, Государственный Эрмитаж, Музей Востока передали в галерею ряА произведений высокого художественного уровня, многие из которых украшают в настоящее время зал классического русского искусства и Западной Европы XVI-XIX вв. К примеру, Государственный Русский музей (Аенинград) передал более 60 произведений, в числе которых наряду с неизвестными художниками и 12 этюдов А. КуинАжи, пейзажи В. Поленова и А. Боголюбова, а также гордость комлекции - картина армянского художника В. Суреньянца «Покинутая». Из Третьяковской галереи мы получили самые разнообразные по стилю и времени создания работы таких известнейших русских художников, как В. Боровиковский, С. Щедрин, В. Верещагин и Аругие (Музей А. Кастеева, 2018).

Зац классического русского искусства Ааёт представление об иконописи, портретной живописи XVIII в., русском классицизме, романтизме и реализме. ЗАесь экспонируются «Портрет Чоглоковой» (сер. 1760-х гг.) А. Аевицкого, «Фрукты» (1840г.) И. Хруцкого, «Неаполитанская набережная» (1829 г.) С. Щелрина, «Портрет В. Самойлова в роли Гамлета» К. Брюллова, «Портрет Е.В. Мазуриной» (1844г.) В. Тропинина, «Море» И. Айвазовского, этюды КуинАжи, пейзажи А. Саврасова, И. Шишкина, В. Поленова и многие Аругие произведения. Комлекция русского искусства XVIII-XX вв. включает работы Рокотова, Кипренского, Верещагина, Репина, Аевитана, БорисоваМусатова, Кустодиева, Петрова-Водкина, Бронникова, Максимова, Павцова. Среди работ советского периода необходимо вылелить шедевры Юона, Кончаловского, Корина, Бродского, Пластова, Сарьяна, Аейнеки, Яблонской и Аругих мастеров.

С произведений русского искусства, переданных в 1935 г. из кучших хранилищ СССР, зарожАалась в Алматы история Государственного музея искусств имени А. Кастеева. О том, каким сокровищем обладает этот храм изобразительного искусства, поведала открывшаяся на Анях выставка «Женщина - богиня, дети - ангелы, цветы - райский саА». 
Популярность Верещагина как художника при его жизни была высока. По свилетельству критика Александра Бенуа, в те времена за границами России из русских художников только Верещагина и признавали. Его выставки неизменно собирали массу народа, хотя вход был платным. Сам художник старался сАелать плату Аоступной, особенно Аля простого АюАа. Сын Верещагина в своих воспоминаниях приводит цифры: на выставке в Петербурге в 1880 г. за 40 Аней побывало 200 тыс. посетителей. На венской выставке в 1881 г. за 26 дней побывало 110 тыс. человек.

За свою творческую жизнь Верещагин много и подолгу путешествовац. В молодости по Кавказу. Затем были Туркестан, Индия, Палестина, Сирия, Япония, Филиппины, Куба, Север России. К этому надо Аобавить и его многочисленные персональные выставки почти во всех столицах Европы, во многих городах США. Особое место в его жизни занимают две поездки в Туркестан. МежАу первым и вторым путешествием в Туркестан по инициативе Верещагина в Петербурге в первой половине 1869 г. была организована «Туркестанская выставка», впервые ознакомившая русское столичное общество с культурой края. Помимо множества этюдов, рисунков, ставших материалом Аля его картин, Верещагин оставил митературные записки о своем пребывании в Туркестане. В них он описывает разные, в том числе и неприглядные (например, рабство), стороны жизни края. Интерес представцяет описание общения с казахами, жившими межАу Ташкентом, Чиназом и Ходжентом. Они занимались хлебопашеством. Хранятся ми художественные работы Верещагина в Казахстане. УАалось выяснить, что Аве картины находятся в запасниках Государственного художественного музея имени А. Кастеева.

В отделе русской живописи проинформировали, что одна из них называется «Горы, окружающие Аепсинскую станицу». Это одна из картин Туркестанского цикла. Передана в Аар национальной картинной галерее Казахстана Третьяковской галереей в 1936 году. Вторая картина - «Ненастье в Гималаях» - сначала была передана в музей Семея (также из Третьяковской галереи), а оттуда - в галерею в Алматы. Полотно «Ненастье в Гималаях» написано по результатам одного из Авух путешествий в Индию (в 1874-1876 и 1882-1883 гг.) (Художественная сокровищница страны, 2015).

В колмекции русского искусства Кастеевки очень много произведений, посвященных женщинам. Их образы испокон веков волнуют умы и сердца художников. Многие из них, такие как Аргунов, Рокотов, Тропинин, Крамской, Аитовченко, Мясоедов, Маковский, Серебрякова, Борисов- 
Мусатов, Петров-Водкин, Бакст, Фацьк, воплотили женскую красоту в своих полотнах. Теперь представилась возможность увидеть их - заботливую мать и светскую Аьвицу, натурщицу и сказочную царевну, скромную учительницу и гувернантку, крестьянку и Ааже представительницу экзотического африканского племени.

Естественно, говоря о женщине, невольно обращаешься к теме Аетей. Картин на Аетскую тематику в Кастеевке тоже предостаточно: от преАставителей императорской семьи, позирующих художнику согласно придворному этикету, Ао крестьянских детей. Они забавцяются, читают, чтото мастерят, сидя на балконе, играют с животными, зарабатывают кусок хлеба Аля своей семьи. Этот мир Аетства из прошлого передан неизвестными художниками первой половины XIX в. Также есть работы Творожникова, Степанова, Корина, Никифорова. Изображения цветов добавили мирическую интонацию - натюрморты, цветущие сады, поляны. Выставка продлится до марта 2015 года (Откуда родом наши сокровища, 2016).

В акварельном зале можно увилеть выставку работ Ивана Шишкина. Масляных картин известного художника, было всего три. Выставка, на которой собраны все 15 произведений художника из фондов музея, проводится впервые. Многие не знали, что художник занимацся графикой, отАавая предпочтение технике офорта, постоянно экспериментируя (иц . 3). На выставке представлены 11 офортов художника, поступившие в 1950-е гг. из Государственного Эрмитажа и Государственного Русского музея (СанктПетербург) (им^. 1). ЕАинственный рисунок в колмекции, выполненный карандашом - «В месу», был передан в дар Государственной Третьяковской галереей в 1936 г. (им . 2).

Первые экспонаты музея поступили с одного из престижных музеев Третьяковской галереи в 1936 г. Прежле музей установиц тесную связь с соседними странами и заключили договора. Позднее, с расширением возможностей и с целью развития престижа организации установилась связь с зарубежными странами. В течение многих цет мы жили под одной крышей с русским народом в СССР, и в те времена произошли многие изменения в искусстве. В стиле казахских художников можно найти сходство с русскими художниками, изменились их взгляды на жизнь, и они начали работать в Аругом направ ениии.

Русские художники, приехавшие в Казахстан, обратили внимание на себя своими кучшими работами. Также из Третьяковской галереи были 
переданы уникальные произведения искусств мучших русских художников как Попов, Репин, Бакст, Коровин, Виноградов, Рерих и Кузнецов.

По словам руководителя Центра классического искусства музея Галины Сырлыбаевой «очень часто недооценивают колмекцию нашего музея, жАут привозных выставок из Москвы, Санкт-Петербурга, из-за рубежа. Но мы владеем очень солидным художественным богатством, Аостоянием стольких поколений художников» (Музей А. Кастеева, 2018). Выставка стала очередным шагом на пути открытия фондов музея. Через женские образы удацось продемонстрировать всю историю русского искусства. По экспозиции можно проследить смену художественных стилей и направлений от параАного портрета XVIII в. Ао кубистических композиций начала XX в.

27 января 2015 г. в Государственном музее искусств РК им. А. Кастеева открылась персональная выставка русского художника Валерия Всеволодовича Каптерева (1900-1981 гг.) - «Основатель алматинского Барбизона», посвященная 115-летию со Аня рожАения.

Более десяти $е$ с с перерывами прове художник из Москвы в Казахстане, регионе практически не известном московской художественной среде. Впервые в Казахстан В. Каптерев приезжает в 1920-1921 гг. в составе Тургайской экспедиции ещё во время учебы во ВХУТЕМАСе в мастерской А. Шевченко.

Практически В.В. Каптерев объездиц весь Казахстан. Бывац в Прибалхашье, прошел и проехал Северный Казахстан от Петропав овска через Акмолинск, Каркаралинск, Семипалатинск до Туркестана. В стремлении познать новый Аля себя мир художник даже кочевац с местными жителями, участвовал в различных научных экспедициях в качестве художника.

Этюды В. Каптерева - это пейзажные композиции с элементами бытового жанра: всегла в «каАре» присутствуют фигуры мюдей, небольшие постройки. КажАый этюА - постановка определенной творческой задачи и ее решение, или поиски этого решения. В 1920-1930-е гг. прошлого века в советском искусстве этюА занимац особое место. А^я быстроменяющейся и неустойчивой художественной среды этого времени, этюА был наиболее подходящей формой самовыражения, решения разАичных творческих задач, в том числе и формального плана. Поэтому, в контексте искусства этого времени Аля Каптерева, работавшего в Казахстане по принципу творческой командировки, эти этюды приобретают статус самодостаточных произведений. 
В годы эвакуации В. Каптерев вновь приезжает в А^ма-Ату, активно участвует в художественной жизни. На обсуждении одной из выставок, представ явшей пленэрные работы Каптерева и его менинградских комлег Т. ГАебовой и В. Стерлигова, А. Черкасский приветствовал всех трех художников, вышедших на этюды, замечательной фразой: «Заложено основание алматинского Барбизона», признав тем самым их достижения на этом поприще.

Заслуга В. Каптерева в том, что он принадлежал к последнему поколению русских художников, которые своим бескомпромиссным творчеством продолжили траАицию русской живописной культуры, иАущей от В. Серова, К. Коровина к их ученикам и последователям - А. Шевченко, А. Куприну, И. Машкову, П. Кончаловскому, Р. Фальку и Аругим. Творчество В. Каптерева - звено в прерванной цепи естественного развития русской живописи (Бакшеев, 1961).

Ранней весной 1926 года отправляется в непростое и Аалекое путешествие из Москвы в южный город Казахстана Аулие-Ата художник Василий РожАественский. В своих воспоминаниях об этой поезАке, он писал, что уже и не помнит от кого узнал об этом городке на границе Казахстана и Узбекистана. Но неизвестность и удаленность не остановили его. Все вызывает восхищение художника: и увиденное по Аороге из окна железнодорожного вагона, и сам город, овеянный Аухом истории и среднеазиатским колоритом с его узкими улочками, особой атмосферой и ритмом жизни. Художник в своих воспоминаниях писал: «Оригинальность азиатского города, ясные безоблачные Ани создали хорошие условия Аля живописи. Палящий зной. Работаю над характерным видом Аулие-Аты: улица около базара. Вся она - однообразно песчано-пепельного цвета... Вот казах на верблюде, в халате цвета песка, подъезжает к кумысной чайхане...» (Основатель алматинского Барбизона, 2015). В ГМИ аулеатинский периоА творчества художника представ ен 43 графическими работами. Как и в случае с В. Каптеревым, Аля заинтересованного читателя даем ссылку на уже опубликованные материалы. Среди представителей старшего поколения русских живописцев, начавших свою творческую карьеру в конце XIX в., в первую очередь следует назвать Бакшеева Василия Николаевича (1862-1958 гг.), народного художника СССР. В 1930 г. он впервые приехал в Казахстан в возрасте 68 мет, один без сопровождения. Путешествие произвело на художника неизгладимое впечатление, о чем он и написал в своих воспоминаниях. В поездке он видит «не только новые пейзажи, но и новых 
Аюдей». Ему самому кажется удивительным, что все это многообразие природы страны он увидел «только на старости». С пафосом, характерным Аля тех мет, художник вспоминает: «Какой простор Аля творчества! Больше нужно ездить, больше вилеть, больше работать Аля того, чтобы запечатлеть Аля потомства индустриальные пейзажи великой эпохи». В 1932 и 1934 гг. Бакшеев повториц свои поезАки по республике. Большинство своих работ он посвятиц шахтерской Караганде и Алма-Ате (Основатель алматинского Барбизона, 2015).

Вторая волна поступлений экспонатов пришлась на 1950-е гг., и тоже из России, в основном из Эрмитажа. Она в свою очередь появцению живописных работ старых мастеров обязана Екатерине II. По словам специалиста по связям с общественностью и внешним связям Музея им. Кастеева Клары Исабаевой «в те времена о монархе судили по его колмекции искусства» (Художественная сокровищница страны, 2015).

В 1950-е гг. предпринимаются и первые попытки работы с частными владельцами произведений искусства. Особо наАо отметить вкцаА Всеволода Теляковского (1894-1963 гг.), художника, чье имя связано со становлением театрально-декорационной живописи в Казахстане. Сын Владимира Теляковского, послелнего директора императорских театров, был сослан в 1935 году из Аенинграда в Казахстан за дворянское происхождение. В разные годы от Теляковского в фонды ГМИ поступицо 94 экспоната русского и западноевропейского искусства, подлинность которых не вызываца сомнений! Некоторые из них были переданы в дар. Особо ценными были портреты его родителей - Вцадимира Аркадьевича и Гурли Аогиновны Теляковских, написанные замечательным русским художником Константином Коровиным.

КажАый экспонат имел свою историю. Например, картина «Аевушка с розами» в 1962 г. была приобретена у сестры знаменитого художника Виктора Борисова-Мусатова - Елены. В музее хранится письмо, в котором Елена Э^ьпидифоровна рассказывала об истории создания этого портрета: «...я позировала Аля картины «Аама на Аестнице»... приходилось Аолго стоять, я уставала. Когда я почувствоваца себя плохо, он (художник) привец меня Аомой. Я невольно прилегла у туалетного столика, на котором стоял букет роз. Брату понравилась моя непринужденная поза, и он слелац набросок... «Вот и вся история этого сюжета».

И^и Аругой интересный пример. Кисти И^ьи Репина приналяежит «Портрет Вильгельма Битнера», журналиста, редактора и издателя научно- 
популярного журнаца «Вестник знаний». Портрет был написан в 1912 г. по просьбе подписчиков журнала, которые решили отметить 10-летний юбилей журнаца и заслуги его редактора. Ао поступления в музей картина находицась в семейном собрании. В 1974 г. она была приобретена у дочери В. Битнера и стала гордостью комлекции.

В 1965 г. за высокий уровень собирательской работы, за научную и популяризаторскую деятельность приказом Министерства культуры СССР музею была присвоена первая категория.

В 1960 г. в фонды ГМИ им. А. Кастеева поступица работа под названием «Аети князей Трубецких», приобретенная у московского колмекционера. И хотя полотно было явно незавершённым, имело эскизный характер, оно приковывацо к себе внимание живописностью, свободным и размашистым мазком уверенного в своих возможностях художника. Привлекателен был и сюжет с особым мирическим настроением: в парке изображены две милые Аевочки с огромной собакой, вдалеке на скамейке ещё одна девочка, вероятно с гувернанткой. Картина была принята на хранение как работа неизвестного мастера конца XIX - начала XX вв. По живописной манере определялся круг художников, близких к Валентину Серову, возможно, его учеников. Путём сложных изысканий было установлено, что работа принадлежит Семену Никифорову, который Аействительно являлся учеником Серова и активным участником выставок передвижников. Были установлены и имена девочек. Ими оказались Аочери князя Петра Николаевича Трубецкого - Софья, Аюбовь и самая младшая - Александра. В настоящее время работа заняла Аостойное место в постоянной экспозиции музея (Исабаева, 2015).

В начале XXI в. американский меценат российского происхождения Алекс Орлов создает фонА Сергея Каммыкова и начинает собирать его работы по всему миру... Кто же этот загадочный Калмыков?!

Уже почти полвека свыше тысячи картин, гравюр, рисунков этого автора явАяются гордостью собрания Государственного музея искусств Казахстана им. А. Кастеева, а мичный фонА Сергея Калмыкова в Государственном архиве Республики Казахстан с его философскими трактатами и Аневниковыми записями, собственноручно переплетёнными.

Ученик М. Аобужинского и К. Петрова-Водкина, юный Сергей Каммыков уже имеет в своем творческом багаже работу «Красные кони». Он написал их в 1911 г. Позже Каммыков будет гордиться, что «Купание красного коня» Петров-Водкин создал, познакомившись с калмыковским полотном, а его самого увековечил в картине. «К свеАению будущих составителей моей 
монографии. В образе томного юноши на этом знамени, вокруг которого можно сплотиться, изображён я собственной персоной!»

В 2015 году в Аар музею свои великолепные картины передали такие известные российские художники как Алексей Фирсов, Алексей Талащук и Казбек Аатифов, выставки которых прошли в музее им. Кастеева.

Уникальная комлекция живописи Государственного музея искусств им. Абылхана Кастеева - достояние нашего государства и народа. Несмотря на колоссальную её ценность, она доступна цюбому желающему. Поэтому приходите сюда чаще, чтобы прикоснуться к векам, которые не повторятся больше никогАа.

\section{Закиючение}

В Аанной статье, важно было выявить круг художников, работавших в Казахстане, в годы, когда казахстанское изобразительное искусство только становицось «на ноги», происходил процесс консолидации немногочисленных творческих сиц. Так или иначе, эти художники побывали в Казахстане, работали зАесь, создавали свои произведения. Среди них были именитые русские живописцы, вошедшие в историю советского искусства. Шелевры казахского и русского искусства позволят зрителю прослеАить историю станов ения и развития казахской национацьной школы живописи, свыше тысячи картин, гравюр, рисунков явцяются гордостью собрания Государственного музея искусств Казахстана им. А. Кастеева.

\section{Список источников информации:}

Алма-Аma. Энииклопедия. (1983). Гц. реА. М.К. Козыбаев. Алма-Ата: Казахская советская энциклопедия. (in Russian)

Азаров А. (2012, 30 октября). Художник правдвг войньг в Туркестане: 170-летие Верешагина. (in Russian)

Бакшеев В.Н. (1961). Воспоминания. М.: ИзА-во Академии художеств СССР. (in Russian)

Исабаева, К. (2015) Искусство обращаться к искусству. $K$ 80-летию Государственного музея искусть им. А. Кастеева. Культура, 177-181. (in Russian) Казахскал ССР: краткая энииклопедия. Т. 4: Язьгк. Аитература. Фольклор. Искусство. Архитектура. (1991). ГА. реА. Р.Н. Нургалиев. Алма-Ата: Казахская советская энциклопедия. (in Russian) 
Музей А. Кастеева (2018). Обрашение 28 января 2021 года к https://www.caravan.kz/gazeta/muzeji-kasteeva-zhenshhina-boginya-detiangely-cvety-rajiskiji-sad-80674/bizona (in Russian)

Откуда родом наши сокровища? (2016, 29 февраля) Караван. Обращение 11 февраля 2021 года к https://www.caravan.kz/gazeta/otkuda-rodom-nashisokrovishha-88121/ (in Russian)

Основатель алматинского Барбизона (2015, 30 января). Обращение 26 января 2021 года к http://www.gmirk.kz/index.php/ru/sobytiya/274-osnovatelalmatinskogo-bar (in Russian)

Постановление Совета Министров Казахской ССР от 26 января 1982 года №38 «О памятниках истории и культуры Казахской ССР Республиканского значения». (in Russian)

Сырлыбаева, Г.Н. (2003). В.В. Каптерев в Казахстане. Сборник докладов международной научной конферениии «Художественныи музей и его раль в контексте современной культурыл», 58-63. Алматы, ГМИ им. А. Кастеева. (in Russian)

Сырлыбаева, Г.Н. Знойное мето 1926-го... (Русский художник В. Рождественский в Казахстане). (2009). ЮНЕСКО и изучение феномена Великого шелкового пути в современном мире. Материаль международной научнопрактической конференчии, 152-154. Алматы: КазНАИ. (in Russian)

Художественная сокровищница страны (2015, 20 марта). Казахстанская правда. Обращение 15 февраля 2021 года к http://www.m.kazpravda.kz/articles/view/hudozhestvennayasokrovishchnitsa-strani3/(in Russian) 


\section{Прихожения}

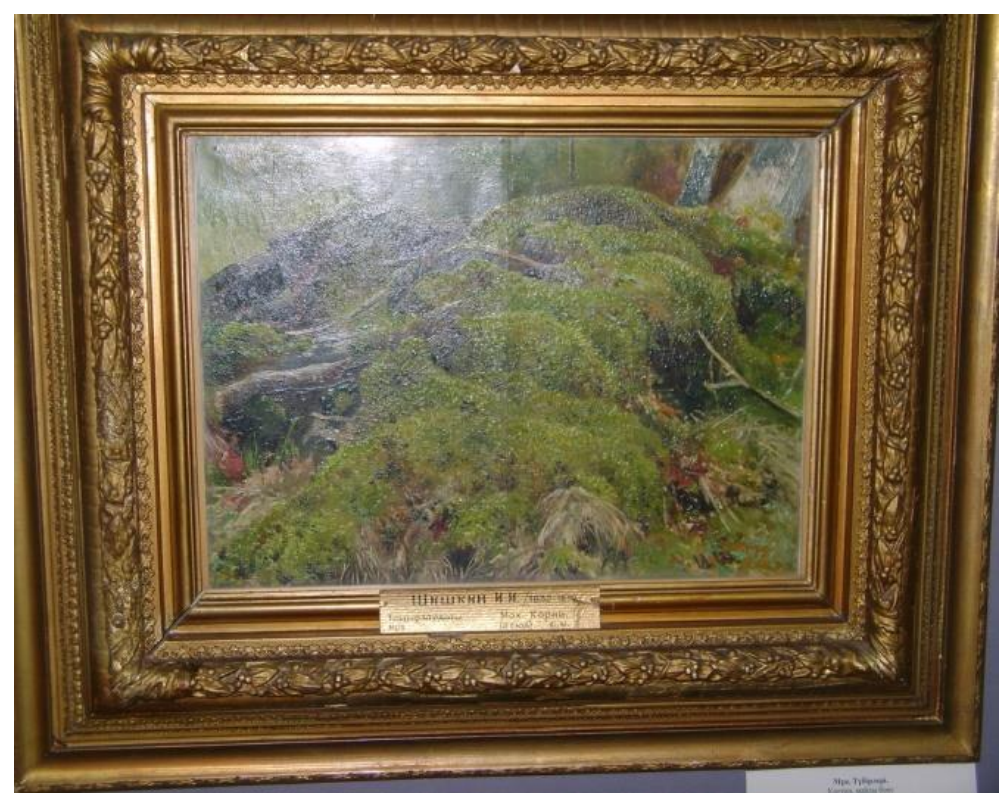

И^^. 1. Шишкин И. «Корни»

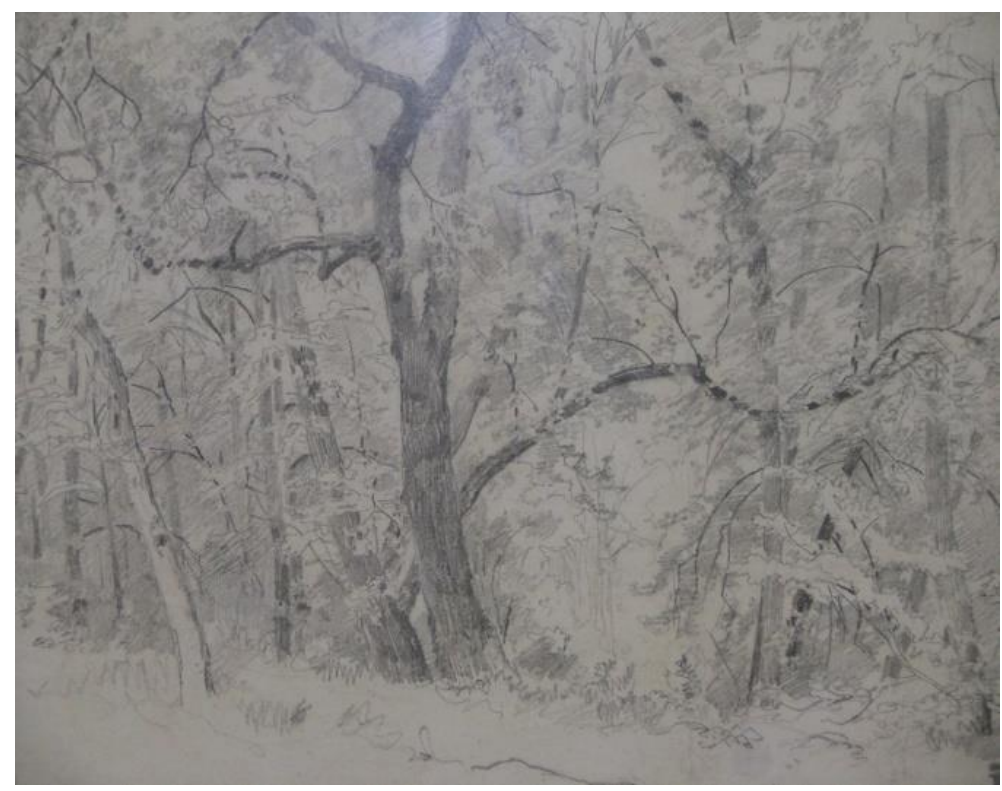

И^^. 2. Шишкин И. «В месу» 


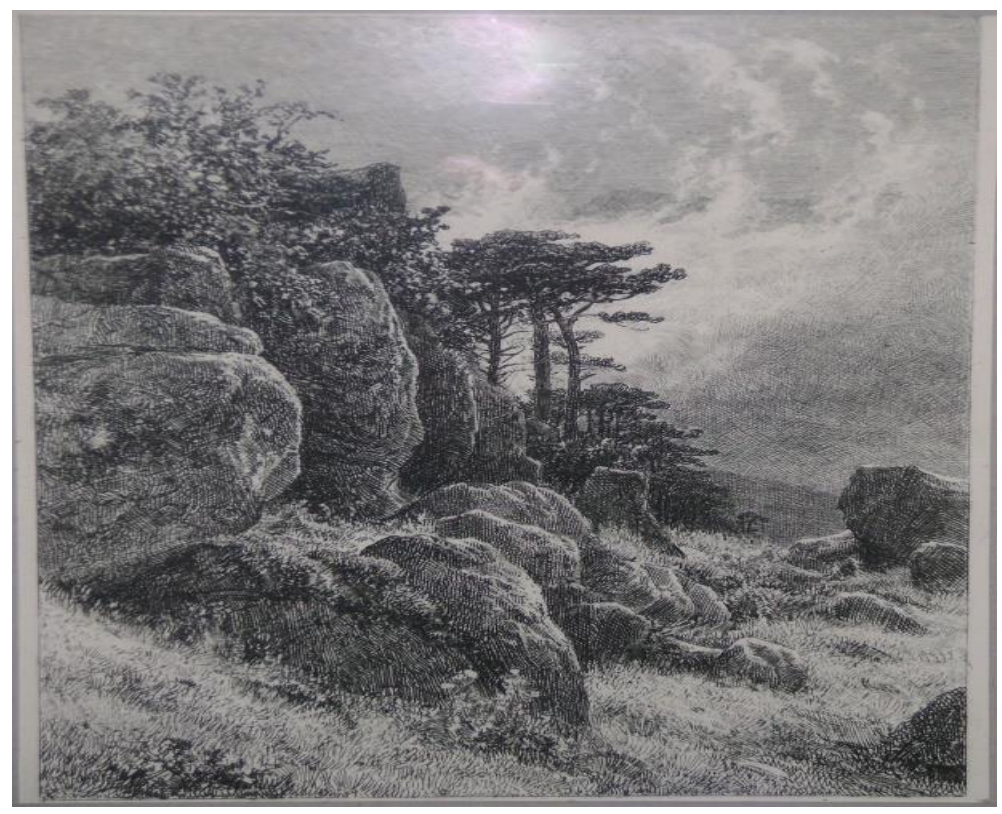

И^^. 3. Шишкин И. «Офорт»

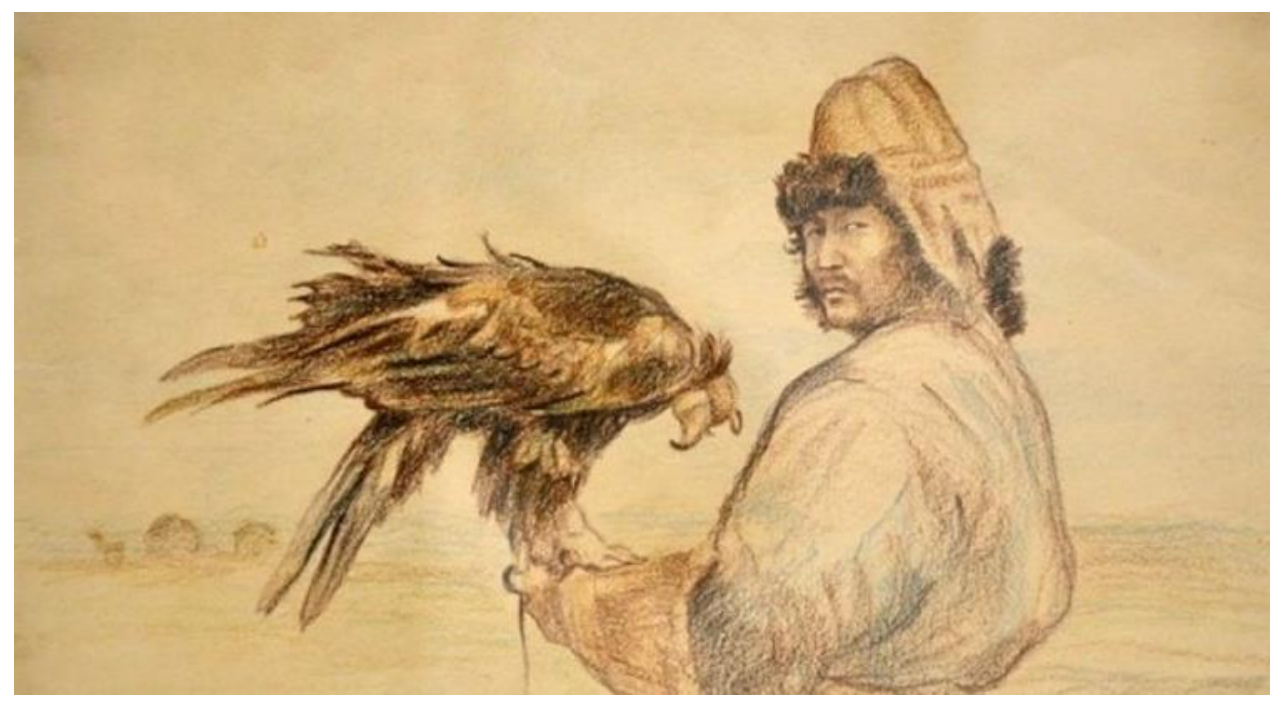

И^^. 4. Каптерев В. «Охотник с беркутом ярки» 


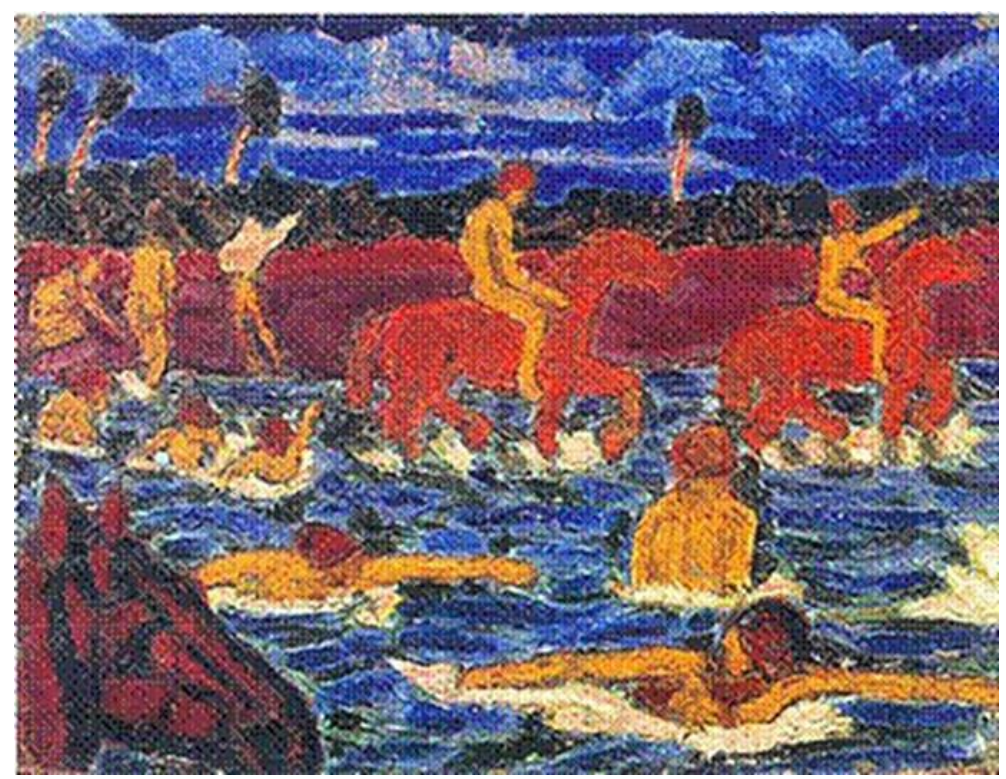

И^^. 5. «Красные кони»

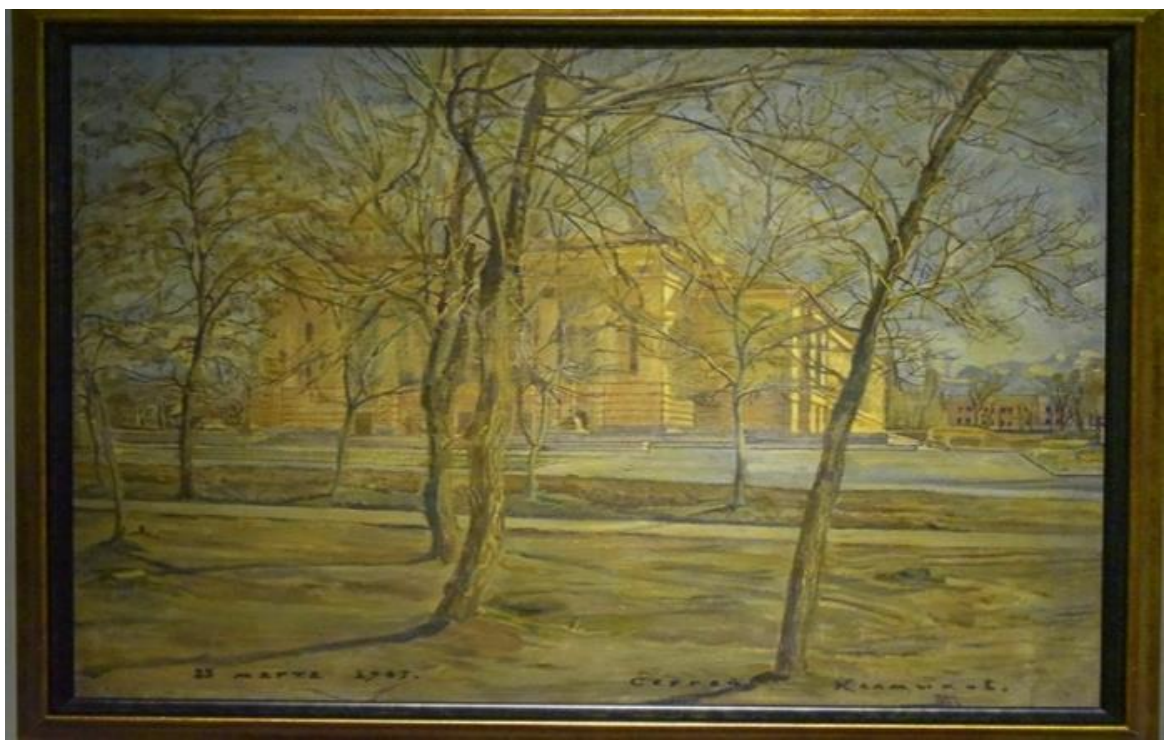

И^м. 6. Калмыков С. «ГАТОБ Оперный театр» 


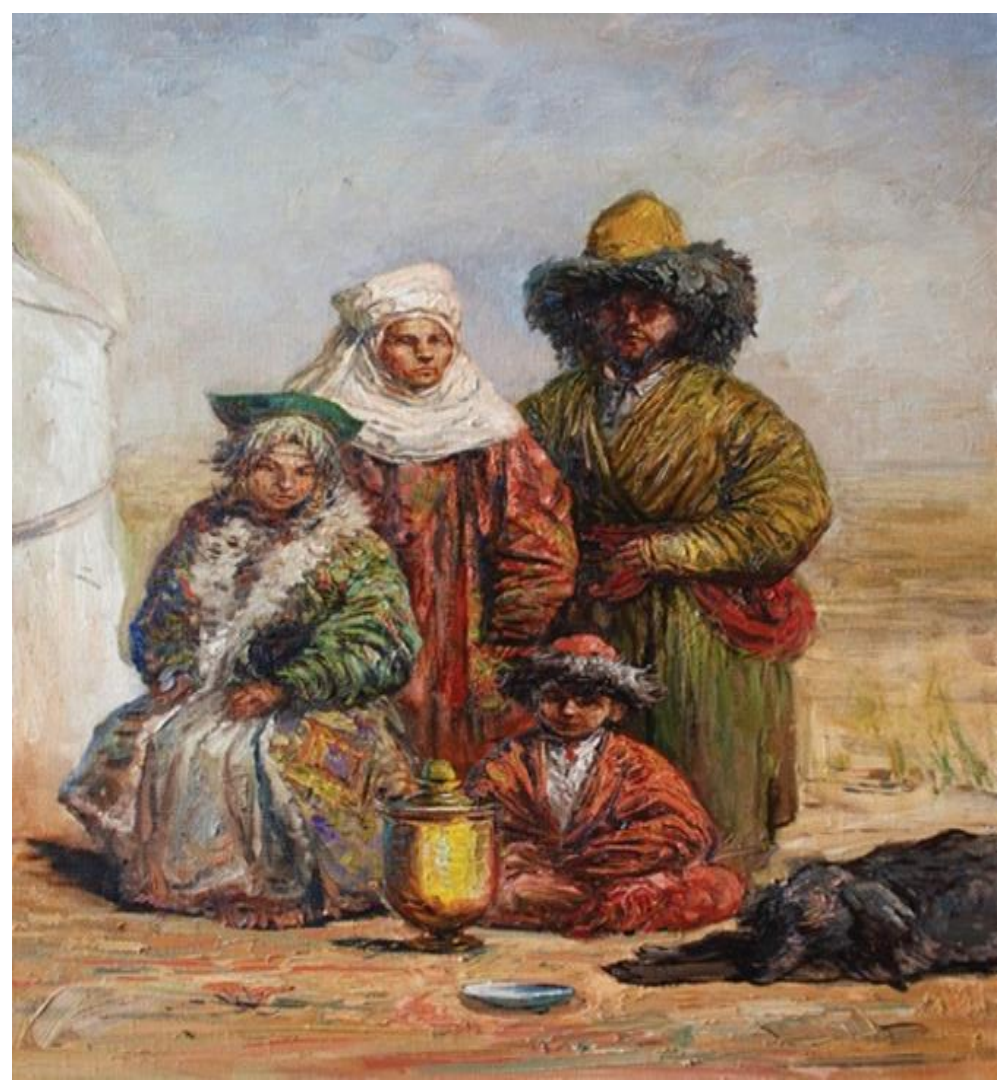

И^^. 7. Калмыков С. «Казахи» 